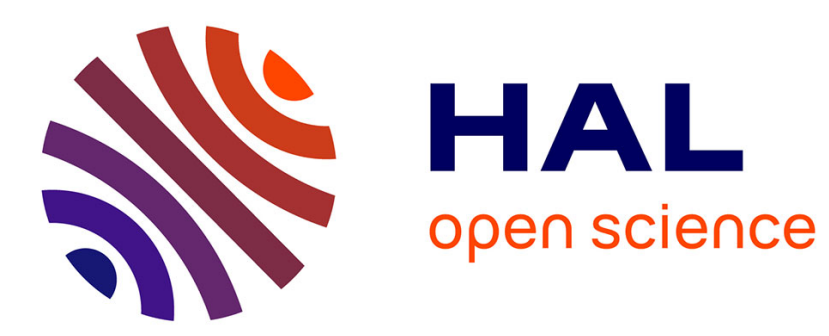

\title{
What is Economic Democracy? An Inquiry into French Cooperatives
}

Damien Rousselière

\section{To cite this version:}

Damien Rousselière. What is Economic Democracy? An Inquiry into French Cooperatives. Studies in Political Economy, 2009, 84, pp.29-46. hal-00730117

HAL Id: hal-00730117

https://institut-agro-rennes-angers.hal.science/hal-00730117

Submitted on 4 Mar 2013

HAL is a multi-disciplinary open access archive for the deposit and dissemination of scientific research documents, whether they are published or not. The documents may come from teaching and research institutions in France or abroad, or from public or private research centers.
L'archive ouverte pluridisciplinaire $\mathbf{H A L}$, est destinée au dépôt et à la diffusion de documents scientifiques de niveau recherche, publiés ou non, émanant des établissements d'enseignement et de recherche français ou étrangers, des laboratoires publics ou privés. 


\title{
WHAT IS ECONOMIC DEMOCRACY? AN INQUIRY INTO FRENCH COOPERATIVES
}

Damien Rousselière

\begin{abstract}
Democracy is, properly speaking, the symbolic institution of the political in the form of the power of those who are not entitled to exercise power - a rupture in the order of legitimacy and domination. Democracy is the paradoxical power of those who do not count: the count of the 'unaccounted for.'
\end{abstract}

Jacques Rancière, "Dissenting Words"

Introduction The opening quotation from Rancière ${ }^{1}$ sums up the scandalous character of what could be an economic democracy in the form of self-managed production - the very form that nineteenth century workers achieved when they tried to realize their democratic dream. ${ }^{2}$ Cooperatives are often distinguished from other forms of productive organizations by their specific social rules: they are characterized by their democratic institutions, although what "democracy" entails is not clearly spelled out ${ }^{3}$ and despite doubts on the reality of these democratic practices. According to Poole, Lansbury, and Wailes, ${ }^{4}$ there are four types of economic democracy: workers' initiatives (e.g., shop-floor controls over the production process); union-based forms of participation (where influence is exercised through bargaining and negotiation over the terms and conditions of employment); forms of industrial democracy developed through state initiatives (and supported by the legislature) that focus on the right of employees or their representatives to participate in decisionmaking in their places of employment; and managerial initiatives on employee involvement designed to increase employee commitment to the firm or to enhance productivity, 
efficiency, and adaptability. Forms of economic democracy range from a German-style market social democracy based on comanagement to selfmanagement, industrial democracy based on trade unions, and other forms of participatory economics. ${ }^{5}$

In investigating the different debates and practices within cooperatives, my approach will be empirical and descriptive rather than normative; I do not intend to show the superiority of any particular conception. As Levine ${ }^{6}$ rightfully notes, this wishful thinking leads to bad interpretations, such as claiming that there is a necessary connection between democracy and social justice. Following Bourdieu, ${ }^{7}$ I take as a starting point the philosophy of language and the epistemology of Wittgenstein, since "what has to be accepted, the given - as one could say, are life forms." ${ }^{\circ}$ Since there is a difference in life forms, there is also a difference in the meaning given to economic democracy. I make the reasonable hypothesis that all periods are characterized by a plurality of phenomenological forms of economic democracy, but that there is a dominant form conventionally accepted at a given time. And around this form there are deviating and alternative ones. Thus, it is possible to think that cooperatives are inhabited by conflicts pertaining to the very essence of democracy. The structure of the article reflects these themes: the first part presents contemporary debates on democracy; the second part discusses cooperatives as a typical example of economic democracy or, in Marx's words, the prerequisite of "a republican system of association of free and equal producers." Inside these forms, all inhabited by contradictions proper to democracy, I will identify three debates: participation versus cooperation, aristocracy versus republic, and community versus cooperatives. After this empirical and positive description, my conclusion will sketch out some normative outcomes.

\section{To What Extent Can We Speak of "Economic Democracy"? The central} shortcoming of the works on this topic is to mistake the concrete historical forms of democracy for democracy as such. ${ }^{10}$ Majority rule, based on the equality of votes, may seem the most natural process by which to gain access to public offices, but it is no more democratic than the lottery process used in the ancient Athenian democracy. ${ }^{11}$ As Jacques Rancière notes, the equation 
of representation with democracy is a recent historical phenomenon; "representation was initially the exact opposite of democracy." 12

The other pitfall of these studies is to adopt a normative standpoint while analyzing concrete forms of cooperatives, and then to condemn them for their betrayal or derivation from the ideal form. I do not endorse this essentialist position: there is no one ideal and constant form of cooperative existing across times and countries. Such an idea is a pseudoconcept in the Wittgensteinian sense of the term. In his Cambridge lectures in November 1933, Keynes emphasized the importance of beginning economic analysis with loose definitions, i.e., vague and flexible ones, and then working progressively towards more precision through the argumentative process - economists need to find common fields of investigation under the form of loose concepts and then work together towards a greater precision. ${ }^{13}$ Following Wittgenstein's investigative method, ${ }^{14} \mathrm{I}$ will set aside the essentialist approach and endorse an existentialist approach (in the literal sense of the term) to democracy.

Jacques Rancière opts for such an approach when he refers to Pericles' apology of Athenian democracy: "Our constitution is called a democracy because power is in the hands not of a minority but of the whole people." 16 Rancière ${ }^{17}$ argues that democracy is a "scandal," as correctly noted by its opponents (e.g., Plato) right from the start - the scandal of the equality of anyone with anyone else. The advantage of this definition is that it does not mistake democracy with the republic (or the constitutional monarchy), as too often happens. Contrary to the latter forms, democracy is not a political regime. Hence, democracy is not guaranteed by any specific institutional design; it is only the expression here and now of the autonomy (i.e., selfruling) of the body politic, as Castoriadis points out. ${ }^{18}$ An empirical approach can detect several internal conflicts of democracy as a specific political organization based on the "popular will," and thus complement corresponding inquiries in political theory. ${ }^{19}$

I will now highlight three questions:

The Determination of the Popular Will A first question pertains to the nature of decisionmaking in democracy and, more exactly, to the process of collective decisionmaking. Two main models exist. Democratic decision- 
making as the outcome of majority and individual votes is the canonical model in cooperatives: each individual is thought of as an isolated monad, she takes her decision fore interno and, as each person is equal, the final decision is the outcome of vote aggregation, depending on the threshold deemed sufficient for each type of decision (simple majority, qualified majority, unanimity etc.). The second conception is based on a compromise between different social groups - it is the model of multistakeholder cooperatives. This second model, more generally a model of communitarian democracy, seems to be gaining in importance. It takes into account the fundamentally pluralist character of contemporary societies. ${ }^{20}$ Thus democracy can be approached in two different ways. First, it embodies a conception of the pacification of politics; it is essentially an institution of compromise (see Boltanski, Thévenot, Habermas, Walzer, Rawls etc.) as an overcoming of "the rhetoric of intransigence." ${ }^{21}$ Conversely, democracy can be thought of as the expression of dissensus. According to Rancière, "the essence of politics is the manifestation of dissensus, as the presence of two worlds in one." 22 Democracy is then the expression of politics as opposed to policy; it does not tolerate any intermediary in the expression of the popular will.

Equality between Citizens: Democracy as a State or as a Process Plato criticized democracy by arguing that its arithmetic equality implied that participation in political decisions required no specific competence. This points to a question of great relevance to cooperatives today: Do they embody an "enlightened" democracy (justifying the specific powers of some) or a direct democracy (with a permanent general assembly)? This leads to the procedural matter of the division of powers: Are all members equal (one person or one group equals one voice) or, on the contrary, unequal on the basis that the more involved members should have a greater say? Following Castoriadis, I am wary of reducing democracy to a mere set of democratic procedures (as Touraine does ${ }^{23}$ ), since democracy also embodies a specific "social imaginary" at an anthropological level. The question should be put differently: is democracy a process requiring education, transparency, access to voting rights only at majority age (or, in a cooperative, at the end of an internship or mandatory training), or does it describe the static situation of a given society? 
Aims and Institutional Forms of Democracy Levine argued against the equation of democracy with social justice because this would suggest that democracy is, by nature, a political form whose general goal is to increase national welfare or the individual well being of each citizen. This confusion appears when democracy is reduced to a set of procedures, such as the protection of minority rights. Thus, a new question emerges: does democracy in a cooperative consist of protecting individual or minority rights (including quorum, veto right, place of the founders, condition of unanimity, and so on)? Or, if it is a dictatorship of the majority, does it have an infinitely extensible scope, since it can decide on its own limitations? ${ }^{24}$ Is democracy a political system that is direct and participatory, embodied in spontaneous and informal practices, or is it based on representation and delegation within institutions? Here again, the opposing pair of concepts is commonly found in sociological and political scholarship, with the participatory form usually being considered the more democratic one. Rancière criticizes the equation of democracy with a particular institutional form or regime. Within cooperatives, democracy, which is not guaranteed by any institutional design, ${ }^{25}$ is inherently fragile because it is always faced with oligarchy, that is, "the government of the best and the defense of the property order." ${ }^{26}$

Setting aside these crucial questions on democracy, any investigation of the nature of economic democracy leads to questions about the very nature of economics. If there is a paradox in connecting economics and democracy, it can be overcome by the fact that we are not reducing democracy to a specific institutional design. It is through specifying the loose concept of economic democracy that we come to question the definition of economics. One can shed light on the issue of economic democracy as a subset of democracy through an empirical inquiry before giving it a theoretical characterization. According to Vienney, ${ }^{27}$ cooperatives are not a self-centred system but are open to the world outside; their concrete forms are closely connected to the sociopolitical and socioeconomic environment. There is no reason why these cooperative forms should be the same across countries and periods. As Spinoza writes in the Ethics, the a priori quest for a general definition is illusory; it only feeds controversies between philosophers who want to explain natural things through the images of these things. ${ }^{28}$ 


\section{Three Questions on Economic Democracy in French Cooperatives It} is reasonable to suppose that if democracy is the expression of a tension between the will of the people and the oligarchy of "those who have titles to present to govern the people: birth, wealth or science," ${ }^{29}$ this tension is even more critical in cooperatives. The survival of the latter as productive organizations is conditioned by the success of their sales, whereas political democracies enjoy greater institutional inertia. I will now take up the question "what forms of democracy can be found in the statutes and practices of cooperatives in France?" Answering this question will require specifying the democratic rules that exist in these organizations along three vectors: domain (determining who has access or the possibility of access to power), form (the division of powers), and scope (what is encompassed by collective decisionmaking).

\section{Domain: Who Are "the People" in the Cooperative? The Debate on}

Cooperation vs. Participation Acquiring their modern form in the nineteenth century, cooperatives were initially unified by the principle of multifunctionality, and organized largely according to uni-stakeholdership. They initially embraced many functions and were based on the project of a global society; the different strands of utopian socialism (as envisioned by Cabet, Owen, Fourier etc.) influenced the cooperative experience in Europe ${ }^{30}$ as well as in North America. ${ }^{31}$ Cooperative experiments had little room to manoeuvre. They were constrained by political authorities (depending on their political objectives), as in the case of mutual aid funds, which were tolerated only when directed by local dignitaries. ${ }^{32}$

Starting with a progressive division of labour between organizations according to their statutes, following the enactment of several specific laws, ${ }^{33}$ the beginning of the twentieth century was marked by the assimilation between unifunctionality and unistakeholdership. The debate between the two Rochdalian traditions identified by Desroche, ${ }^{34}$ i.e., the cooperative tradition (of associated users/consumers) and the participatory tradition (of associated producers), led to workers being refused membership in English cooperatives and wholesalers, and then (pace Gide ${ }^{35}$ and his program for the complete cooperatization of the economy) to consumers' cooperatives 
no longer selling the products of their own factories.

The evolution of the relations between cooperation and employee participation in profits, ownership of capital, and management led to the emergence of a dogma enshrined by the cooperative congresses of Paris (1937) and Vienna (1966) - "it enshrined the priority of the consumer and, without excommunicating the proponents of profit-sharing, it did not mention their position and proposals, to which the codified principles make no reference at all." ${ }^{6}$ From then on, the notion of double quality became dominant. This notion was based on the principle of services given to users and on the participation of these users in the management of the enterprise, as well as in the ad hoc formation of cooperative executives. National laws were usually founded on the assumption of a homogeneous social basis, that is, on the reduction of membership to the sole category of users, thus reducing the cooperative experiences based on larger social groups and diverse interest groups. ${ }^{37}$ This consensus around self-management and autonomy (beneficiaries' participation in management distinguishes cooperatives from capitalist or state enterprises) led to the imposition of users' cooperatives as the dominant model. This influenced the form of producers' cooperatives. In France, the general law on cooperation (1947) conceptually subsumes workers in producers' cooperatives under the category of users of the cooperative (i.e., those who enjoy the benefits of the service - selfemployment - provided by the cooperative).

Does cooperative activity embody any general interest, or does it defend only the interest of its members? This point was central to Marx's opposition to workers' cooperatives. As soon as cooperatives supplement public policies, democratic rules are not made simply on the basis of the free agreement of their members (through a contract), but are strongly constrained by a legal framework. New laws introduced in 1947 imposed a principle of equality between members and linked the cooperative as a closed organization to the general interest of the community in which it operates. For instance, an important part of the capital is considered to be indivisible and to constitute collective property. In the case of a cooperative's disappearance, this collective property has to be given (as an altruistic gift) to another cooperative or to the state. 
At the heart of the evolution of the international cooperative movement, there is a reflection on the internal form of democracy and on how to think through the relationship between the organization and its environment (autonomy vs. supplementing public action; exclusive benefit of the members vs. altruistic goals). The 1966 declaration of the International Cooperative Alliance (ICA) lays out four principles concerning the characteristics of cooperatives' members (volunteering, openness, nondiscrimination, and responsibility). The democratic principle of autonomy governs cooperative decisionmaking: "their affairs should be administered by persons elected or appointed in a manner agreed by the members and accountable to them." The ICA also mentions that education should complement the action of the cooperative and specifies that the cooperative movement should aim to educate the general public. "The commission classified into four groups those whom a cooperative movement should educate: the members, officers, employees, and the general public." 38

The other related question on the nature of the cooperative people concerns the relations between multistakeholdership and multimembership, given that a current transition is taking place from the double quality to multimembership. It is held that cooperatives do not benefit their members exclusively and should also take into account (at different levels) their relations with the different actors of their environment, thus demonstrating their social utility or collective utility function. ${ }^{39}$ Although there is a difference between multistakeholdership (which takes into account the interests and opinions of the different parties interested in the action of the enterprise or its effects) and the multishareownership, there is also a historical tendency for the two forms to coincide. For instance, as the number of employees increased, the question became crucial in producers' cooperatives (other than workers' cooperatives). The representation of the distinct interests of employees has been made possible at the level of the board of directors by a succession of laws concerning agricultural cooperatives (since 1972), as well as artisans' and fishers' cooperatives (since 1983).

Form: Is the Cooperative an Aristocracy or a Democracy? The division of powers seems to be the outcome of two contradictions, located respec- 
tively in the definition of equality and in the decisionmaking process. With respect to equality, the definitions proposed by Plato and Aristotle remain relevant here: "But equality is of two sorts. One sort is numerical equality: the other sort is equality proportionate to desert. 'Numerical equality' means being treated equally, or identically, in the number and volume of things which you get; 'equality proportionate to desert' means being treated on the basis of equality of ratios." ${ }^{40}$ According to Aristotle, each form is the basis of a specific type of constitution - numerical equality is the basis of democracy and proportional equality is the basis of oligarchy. In the Republic, Plato defines this oligarchy (the government of a small number) as an aristocracy, that is to say, the government of the best.

This question - the government of the best or the government of all by all — runs like a red thread through the history of the cooperative movement. In the Inaugural Address of the International Workingmen's Association (IWA), Marx praises the cooperative movement as a great "victory of the political economy of labour over the political economy of property," ${ }^{41}$ yet makes two sets of critical remarks that limit the scope of his praise. On one hand, cooperatives lack an internal dynamic that could drive their expansion. Restricted "to the dwarfish forms into which individual wage slaves can elaborate it by their private efforts, the cooperative system will never transform capitalist society" 42 and "will never be able to arrest the growth in geometrical progression of monopoly, to free the masses nor even to perceptibly lighten the burden of their miseries." ${ }^{33}$ Thus, it cannot be the most important terrain of workers' action. Furthermore, in a capitalist society, producers' cooperatives cannot attain a definitive form of associational work: "they naturally reproduce, and must reproduce, everywhere in their actual organization all the shortcomings of the prevailing system." ${ }^{44}$ This is why Marx's preparatory report for the congress of the IWA recommends that there should be no auxiliary class (nonmember workers) in cooperatives. Existing cooperatives are, at best, "transitional forms from the capitalist mode of production to the associated one." 45 Yet these two critical reservations - the first dealing with the means to achieve the general abolition of wage-labour and the second taking up the very nature of cooperative work in current society - do not strip cooperation of its importance. Though it 
does not constitute the exclusive, or even principal means of workers' action, the cooperative idea is closely associated, in Marx's view, to the final goal of workers' struggle. "Its great merit is to practically show, that the present pauperizing and despotic system of the subordination of labour to capital can be superseded by the republican and beneficent system of the association of free and equal producers." 46

By contrast, as Espagne emphasized, several authors or activists feared that cooperatives would become an ochlocracy ("government by the mass, the multitude, or the mob" ${ }^{47}$ ) and believed that only an enlightened minority, accustomed to the technical and economical imperatives that arise in such organizations, could ensure sound cooperative management. Espagne refers here to what he calls an aristocratic-professional tradition that is dominant in French cooperation. Reform of the principle of responsibility (on which the idea of self-management was based) has led to the emergence of the figure of the social representative, who bears responsibilities on the general model of a commercial firm ${ }^{48}$ and invalidates formal equality between members (the elected executive becomes primus inter pares). This last point has been exacerbated for cooperatives since the need to use a secret ballot to elect board members was abolished (in 1992), despite the fact that this procedure is generally recognized as the condition of a genuine and free vote (see Article 21 of the Universal Declaration of Human Rights of 10 December 1948).

The second question is: should we recognize intermediaries between the individual and the collective in the construction of the general will? That is to say, are certain groups special (because they defend specific interests, such as those of consumers or producers)? This line of thinking, similar in many countries, led to an important adjustment of cooperative principles since it called into question "'uni-stakeholdership' (the homogeneity of the social base matches the single function of the cooperative) and Selbsthilfe (the activities of cooperatives are directed towards the satisfaction of the needs of their own members)." 49 Two scenarios for the opening of the membership of French cooperatives emerge. First, with the possibility of nonmember investors (outside investors owning up to 49 percent of the capital), there can be two categories of associates within cooperatives - those who join 
in order to further the achievement of the cooperative's institutional goals (the production of its services) and those who seek a high return on their investments. This is a hybrid of cooperative and capitalist rules (political rights are given to the providers of capital). The second approach is that used by the SCIC (Société coopérative d'intérêt collectiflCooperative Society of Collective Interest) - the different categories of membership reflect a diversification of the organization's ends, which are to serve not only its members, but also the community and the general interest. ${ }^{50}$

More generally, there is controversy over the importance and nature of the legal framework in which these practices occur, and over the return of a conception of democratic rules as free agreement among the parties involved. The appearance of newcomers to the system or of intermediaries adds new practices of influence (and hence a multipartnership) to formally recognized power practices, which extend over institutional and interpersonal networks of partnership or exchange. Thus, the creation of many organizations is based explicitly on downplaying the necessity of a formal framework of democratic rules. This recalls Laville's conceptualization of these practices in terms of a "mix of resources" ${ }^{1}$ : what matters in distinguishing these organizations from others is, on one hand, their official objectives and, on the other hand, the mix of (market, nonmarket, and nonmonetary) resources they deploy. It is possible, then, to speak of social enterprises.

Scope: The Community vs. Cooperative Debate Thinking through the scope of the decisions made by cooperatives seems to be linked to cooperatives' capacity to be ruled by their own laws. Can they define and implement their own laws? Let us mention here the example of labour law in workers' cooperatives in France. Espagne has clearly shown how labour relations in cooperatives, which were originally sui generis, evolved into subordinate wage-earning relations. ${ }^{52}$ The law of 19 July 1978, which gave workers' cooperatives their modern status, formally equated cooperative members with employees, and thus subjected them to the general Labour Code (like any employee). However, French law includes adjustments that take into account the specificity of contracts of association and thus the capacity of 
cooperatives to develop their own laws. For example, a cooperative contract can force employees to ask to be admitted as cooperators, or face being considered to have resigned from their jobs; it can stipulate that to withdraw from membership in the cooperative is tantamount to resigning from one's job in it; and it can force employees to contribute to the cooperative's capital (by withholding a share of salary at the source). In the final analysis, this boils down to the transformation of employees into co-entrepreneurs, which, for example, justifies the creation of taxi cooperatives.

More generally, this opens up the debate concerning cooperative and community, summed up nicely by Desroche in Le Projet Coopératif: "we were expecting the community but we got the cooperative." ${ }_{33}$ This meant that every alternative organization imagined by utopian writers at the moment of its birth was considered to be an exclusive whole. In France, historically, the cooperative vs. community debate developed more specifically around the movement of communities of work (which was initiated by the Communauté Boimondau — "watch cases of the Dauphiné"), the key issue of which was the ends and scope of democracy. ${ }^{54}$ Emerging in the postwar period, these communitarian experiences developed in France around a specific métier (trade) (for example, the production of watches for Boimondau) and created a whole community life around it. Later, they gathered in the Entente Communautaire (Community Alliance). Their proponents were drawn mostly from the Resistance and associations of popular education. ${ }^{55}$

"In the community, rules are freely discussed and accepted by all" 56 : democratic decisions come from a unanimous consensus (with different devices to protect minority interests); the leader's mandate is deemed imperative and is hence revocable at any time. The cooperative's running often hinges on the charismatic figure of the leader (such as Marcel Barbu and, later, Marcel Mermoz in Boimondau) who is the true mediator and the arbiter between individual wills. This is shown in Mermoz's book of interviews, which explains the community experience from a practical perspective. ${ }^{57}$ The idea of an enlightened democracy is consistent with the (progressively abandoned) objective of linking incomes to the human value of workers, as evaluated by subordinates and superiors. In these communi- 
ties, the concept of democracy differs in degree, rather than in nature, from that of cooperatives, since democratic participation is calculated on the basis of activity and work, which implies considering all activity (such as being a spouse, a mother, a child) as work.

Moreover, this communitarian movement is based on the necessity of education to promote autonomy, helped by the right to information and training for all. As Picut $^{58}$ and Demoustier ${ }^{59}$ remind us, this will lead to a quite pacific coexistence between the Entente Communautaire and the General Confederation of Workers Cooperatives, since labour communities ended up subscribing to the latter before disappearing as they relinquished their particularities and endorsed the rules of other cooperatives (such as reduction of the share of "nonproductive" work in the calculation of salaries and rejection of the principle of unanimity in favour of the majority principle). According to Demoustier, communitarian enterprises followed the path of Boimondau - the leaders went from the status of organizers to CEOs, and communities became workers' cooperatives. Mermoz left Boimondau in 1951 on the ground of its "normalization" and "collective suicide."

Conclusion What are the main conclusions of this historical sketch of the evolution of French cooperatives? What lessons can be drawn with respect to the different forms of economic democracy that this history brings to light?

First, the historical debate between emerging and institutional forms of social economy, or between old and new cooperatives, cannot be reduced to the debate between representative and participatory democracy. Rather, each period reveals how new generations of organizations confronted the representations of the nature of democracy then current. This history of cooperation is the history of the relation between the two Rochdalian traditions noted by Henri Desroche: cooperation (the users of the service have the political right to manage the enterprise) and participatory (the providers of this service - the workers - have these same political rights). If associationism's beginnings are marked by the confusion between these two traditions, the shift to social economy established a separation in terms of 
status (cooperatives are categorized according to their function). Confirming the separation between political association (trade union) and cooperative enterprise, the users' cooperative became the generally dominant form. The current period of change is marked by the appearance of new hybrids that combine capitalist rules (power is granted to shareholders/investors of capital) and participatory rules (power is granted to the workers).

This analysis shows the paradox intrinsic to the history of the cooperative movement, which evolved from an alternative type of structure to a structure integrated within the very contradictions of capitalism. ${ }^{60}$ Going back to the debate on economic democracy laid out in the introduction, the current diversification of cooperatives highlights new conceptions of democracy, not only in older organizations but in emerging ones as well. The previous consensus on the supposed dual quality of democratic organizations does not exist any more, neither in changing large organizations nor in emerging ones. Communitarian democratic structures, organized around groups sharing specific interests, are the most successful, but there is no debate about their being a government of the people by the people. The constitution of an aristocratic oligarchy (based on wealth or knowledge) is common to them all, although these experiences are a typical example of "control by the basis" according to Poole, Lansbury, and Wailes. ${ }^{61}$ Finally, in terms of procedures, democracy tends to be equated with representation. These three trends show that cooperatives are part of the general transformation of democratic societies.

All of this raises several key questions. If, according to Rancière, dissensus is a fundamental feature of democracy, is dissensus possible in cooperatives, when their very existence is constantly threatened by issues of profitability and failure to adapt to users' demands? By contrast, democratic societies have different channels to allow the expression of conflicting claims (such as strikes and electoral campaigns) without constantly threatening the existence of society in general. Two remarks flow from this.

First, is the constitution of an oligarchy an essential tendency, because these structures have a strong economic component and require high technical skills? Voting, then, would involve merely approving or rejecting 
the elected or technical oligarchy in power. Thus, it is all the more necessary to set out procedures to guarantee fair access for all to the different positions within the organizations and to secure for each member the capacity to exercise his or her autonomy.

Second, the coherence of the "cooperative people" is threatened constantly. Conflict threatens the existence of the organization, which grows more complex as a result of the constitution of a technostructure and the diversification of social groups bearing different interests. It is important to stress the importance of the cooperative imagination and, thus, of cooperative education. In this regard, the introduction of capitalist dimensions within cooperatives may be a sea change.

I chose not to focus on the debate over different concepts of democracy, from Rawls to Sen, and their relation to social justice. Such a normative approach would entail asking which procedure best ensures expression of the popular will, or leads to the greatest economic efficiency. ${ }^{62}$ One could ask about the best social arrangement to promote workers' rights. ${ }^{63}$ In any case, specific procedures (e.g., education, meetings, transparency, and limitation of mandates) are the very guarantee of cooperatives' democratic dimensions here and now.

As an economic structure, cooperation cannot overcome capitalism, as Estrin and Derek as well as Gunn have shown in their analyses of cooperatives' degeneration when in contact with the market. ${ }^{64}$ At a normative level, it could be seen as a renewal of the proposals laid out by associationist socialism (from Buchez or Blanc to Jaurès). ${ }^{65}$ As Jaurès puts it, "the democratic state is the supreme cooperation towards which all cooperation tends as to its limit." ${ }^{66}$ Economic democracy, conceptualized in the wake of Rancière as a permanent struggle against the oligarchy of owners, lies in the coordination of economic action (through cooperation), workers' demands (through trade unions) and political action, since, more than ever, the social power of wealth relies on state power. 


\section{Notes}

I am grateful to Geneviève Rousselière, François Espagne, Paul Leduc Browne, and two referees for their helpful comments on an earlier version of this paper, which was written while I was a postdoctoral fellow at the Canada Research Chair on the Social Economy at the Université du Québec à Montréal.

1. Jacques Rancière, "Dissenting Words: A Conversation with Jacques Rancière, by Davide Panagia," Diacritics 30/2 (2000), pp. 113-126.

2. Jacques Rancière, The Nights of Labour: The Workers' Dream in Nineteenth-Century France (Philadelphia, PA: Temple University Press, 1989).

3. C. Gunn, "Markets against Economic Democracy," Review of Radical Political Economics 32/3 (2000), pp. 448-460; R. Spear, "Governance in Democratic Member-Based Organisations," Annals of Public and Cooperative Economics 75/1 (2004), pp. 33-59; R. Varman \& M. Chakrabarti, "Contradictions of Democracy in a Workers' Cooperative," Organization Studies 25/2 (2004), pp. 183-208.

4. M. Poole, R. Lansbury, and N. Wailes, "A Comparative Analysis of Developments in Industrial Democracy," Industrial Relations 40/3 (2001), pp. 490-525.

5. M. Albert, Parecon: Life after Capitalism (London \& New York: Verso, 2003); W. MüllerJentsch, "Industrial Democracy: From Representative Co-determination to Direct Participation," International Journal of Political Economy 25/3 (1995), pp. 50-60.

6. D.P. Levine, "Justice and Economic Democracy," Review of Political Economy 10/3 (1998), pp. 343-363.

7. Pierre Bourdieu, Pascalian Meditations (Stanford: Stanford University Press, 2000).

8. Ludwig Wittgenstein, Philosophical Investigations (Oxford: Blackwell Publishing, 1953), section 2 .

9. Karl Marx, "Cooperative Labour," in International Workingmen's Association, Instructions for the Delegates of the Provisional General Council (1866), B. Selman, (trans.), <http://www. marxists.org/history/international/iwma/documents/1866/instructions.htm\#05>.

10. Cornelius Castoriadis, Figures of the Thinkable (Stanford: Stanford University Press, 2006); C. Castoriadis, La montée de l'insignifiance (Paris: Éditions du Seuil, 1996); Levine, "Justice and Economic Democracy."

11. Castoriadis, Figures of the Thinkable; Jacques Rancière, The Hatred of Democracy (London \& New York: Verso, 2007).

12. "Everyone knew this at the time of the American and French Revolutions. The Founding Fathers and many of their French emulators saw in it precisely the means for the elite to exercise in fact, in the name of the people, the power that the elite is obliged to recognize is theirs but which it could not exercise without ruining the very principle of government."

13. J.B. Davis, "Common Sense: A Middle Way between Formalism and Poststructuralism?" Cambridge Journal of Economics 23/4 (1999), pp. 503-515.

14. B. Savickey, Wittgenstein's Art of Investigation (London \& New York: Routledge, 1999).

15. Rancière, The Hatred of Democracy; J. Rancière, "Ten Theses on Politics," Theory and Event 5/3 (2001); J. Rancière, Disagreement, Politics and Philosophy (Minneapolis, MN: University of Minnesota Press, 1998).

16. Thucydides, The Peloponnesian War, Rex Warner, (trans.), with an introduction by Moses Finley. Revised edition (Harmondsworth, UK: Penguin, 1972), II, 37, p. 145.

17. Rancière, The Hatred of Democracy.

18. Castoriadis, Figures of the Thinkable.

19. Bruno Bernardi, La Démocratie (Paris: Flammarion, 1999); Benoît Lévesque, "Mondialisation, démocratie plurielle et économie sociale et solidaire," Économie et solidarités, Numéro hors série: "Économie sociale et solidaire: une perspective Nord-Sud," 2003, pp. 103-121; Levine, "Justice and Economic Democracy."

20. L. Boltanski and L. Thévenot, On Justification: Economies of Worth (Princeton, NJ: Princeton University Press, 2006).

21. Albert O. Hirschmann, The Rhetoric of Reaction (Cambridge, MA: Harvard University Press, 1991). 
22. Rancière, "Ten Theses on Politics."

23. Alain Touraine, Qu'est ce que la démocratie? (Paris : Flammarion, 1994).

24. Castoriadis, Figures of the Thinkable.

25. Danièle Demoustier, L'économie sociale et solidaire (Paris: Syros, 2001).

26. Rancière, The Hatred of Democracy.

27. Claude Vienney, "Économie sociale," in E. Dülfer, (ed.), International Handbook of Cooperative Organizations (Göttingen: Vandenhoeck and Ruprecht, 1994), pp. 287-292.

28. Baruch Spinoza, Ethics (London: J. M. Dent and Sons, 1910) p. 66.

29. Rancière, The Hatred of Democracy.

30. Danièle Demoustier and Damien Rousselière, "Social Economy as Social Science and Practice: Historical Perspectives on France," in J. Clary, W. Dolfsma, and D. Figart, (eds.), Ethics and the Market: Insights from Social Economics (London \& New York: Routledge, 2006), pp. $112-125$.

31. From the 1840 s to the 1860 s, some reformers, such as Albert Brisbane and Horace Greeley, imported the ideas of the Frenchman Charles Fourier into the United States; they inspired the formation of associative colonies and the establishment of the "Associationists of the United States of America" movement. Other communities, such as Icaria, were created according to the theory of the Christian socialist Etienne Cabet, and tried to develop a federation of socialist colonies.

32. A. Gueslin, L'invention de l'économie sociale (Paris: Economica, 1998).

33. Demoustier, L'économie sociale et solidaire.

34. Henri Desroche, Sociétaires et compagnons (Paris: Éditions Ouvrières, 1981), p. 140.

35. Charles Gide, La coopération (Paris: Sirey, 1910).

36. François Espagne, "Coopération et participation: une antinomie historique?" Paper presented at Conférence internationale sur la coopération et l'économie de la participation (February 1997), p. 3.

37. François Espagne, "L'entrepreneuriat coopératif dans l'Europe de l'an 2000," Revue internationale de l'économie sociale 79/275-276 (2000), pp. 167-182.

38. O.R. Krishnaswami, "The Principles of Cooperation: A Historical Survey and a Review," Annals of Public and Cooperative Economics 39/4 (1968), p. 602.

39. G. Lindsay and L. Hems, "Sociétés Coopératives d'Intérêt Collectif: The Arrival of Social Enterprise within the French Social Economy," Voluntas: International Journal of Voluntary and Nonprofit Organizations 15/3 (2004), pp. 265-286.

40. Ernest Barker, (ed.), The Politics of Aristotle (Oxford: Oxford University Press, 1946), Book V, I section 12, p. 205.

41. Karl Marx, "Inaugural Address of the International Working Men's Association," 1864, $<$ http://www.marxists.org/archive/marx/works/1864/10/27.htm>.

42. Marx, "Cooperative Labour."

43. Marx, "Inaugural Address."

44. Karl Marx, Capital, vol. III (London: Lawrence \& Wishart, 1959), p. 440.

45. Ibid.

46. Marx, "Cooperative Labour." See also B. Jossa, "Marx, Marxism and the Cooperative Movement," Cambridge Journal of Economics 29/1 (2005), pp. 3-18.

47. Espagne, "Coopération et participation."

48. Espagne, "L'entrepreneuriat coopératif," p. 179.

49. Ibid.

50. Lindsay and Hems, "Sociétés Coopératives d'Intérêt Collectif."

51. Jean-Louis Laville, (ed.), L'économie solidaire (Paris: Desclée de Brouwer, 1994).

52. François Espagne, "Le principe de la gestion démocratique dans les sociétés coopératives," Les Cahiers de l'Institut de Coopération Sociale Internationale 4 (1999).

53. Henri Desroche, Le projet coopératif(Paris: Éditions Ouvrières, 1976).

54. L. De Bettignies and G. Hofstede, "Communauté de travail 'Boimondau': A Case Study in Participation," International Studies of Management and Organization 7/1 (1977), pp. 91-116.

55. Danièle Demoustier, Entre l'efficacité et la démocratie (Paris: Editions Entente, 1981). 
56. P. Picut, "L'actualité de Boimondau," Économie et Humanisme 56/341 (1997), pp. 26-27.

57. M. Mermoz, L'autogestion, c'est pas de la tarte (Paris: Le Seuil, 1978).

58. Picut, "L'actualité de Boimondau."

59. Demoustier, Entre l'efficacité et la démocratie.

60. Gunn, "Markets against Economic Democracy"; Benoît Lévesque, "State Intervention and the Development of Cooperatives (Old and New) in Québec, 1968-1988," Studies in Political Economy 31 (1990), pp. 107-140; Vienney, "Économie sociale."

61. Poole, Lansbury and Wailes, "A Comparative Analysis of Developments."

62. A question theorized in various ways by $\mathrm{O}$. Williamson, The Economic Institutions of Capitalism (New York: The Free Press, 1985), H. Hansmann, The Ownership of Enterprise (Cambridge and London: Harvard University Press, 1996), and Samuel Bowles, David Gordon, and Thomas Weisskopf, Beyond the Wasteland (Garden City, NJ: Anchor Press, 1983).

63. Levine, "Justice and Economic Democracy."

64. S. Estrin and J. Derek, "The Viability of Employee-Owned Firms: Evidence from France," Industrial and Labor Relations Review 43/2 (1992), pp. 323-338; Gunn, "Markets against Economic Democracy.”

65. Danièle Demoustier and Damien Rousselière, "L'économie sociale et coopérative des associationnistes," Annals of Public and Cooperative Economics 76/4 (2005), pp. 517-541.

66. Jean Jaurès, "Critique de l'économie sociale," in La Petite République Socialiste (1903). Reprint in Revue internationale de l'économie sociale, 79/275-276 (2000), p. 37. 